Lindwall, C.W., and D.T. Anderson. 1981. Agronomic evaluation of minimum tillage systems for summer fallow in southern Alberta. Can. J. Plant Sci. 61:247-253.

Logsdail, D.E., and L.R. Webber. 1959. Effect of frost action on structure of Haldimand clay. Can. J. Soil Sci. 39:103-106.

SAS Institute. 1989. SAS/STAT user's guide. Version 6. 4th ed. Vol.2, SAS Inst., Cary, NC.

SAS Institute. 1990. SAS language: Reference. Version 6. 1st ed. SAS Inst., Cary, NC.

Siddoway, F.H. 1963. Effects of cropping and tillage methods. dry aggregate soil structure. Soil Sci. Soc. Am. Proc. 27:452454.

Sillanpää, M., and L.D. Webber. 1961. The effect of freezingthawing and wetting-drying on soil aggregation. Can. J. Soil Sci. $41: 182-187$.

Smika, D.E. 1990. Fallow management practices for wheat production in the central Great Plains. Agron. J. 82:319-323.

Statistics Canada. 1992. Agricultural profile of Alberta. Part 1. 1991 Census. Statistics Canada, Ottawa, ON.

Unger, P.W. 1982. Surface soil properties after 36 years of cropping to winter wheat. Soil Sci. Soc. Am. J. 46:796-801.

Wenhardt, A. 1962. Surface clod production characteristics of some tillage machines on a clay loam soil. Can. Agric. Eng. 4:33-35.

Woodruff, N.P, and W.S. Chepil. 1958. Influence of one-way-disk and subsurface-sweep tillage on factors affecting wind erosion. Trans. ASAE 1:81-85.

Zobeck, T.M. 1991. Soil properties affecting wind erosion. J. Soil Water Conserv. 46:112-118.

Zobeck, T.M., and T.W. Popham. 1990. Dry aggregate size distribution of sandy soils as influenced by tillage and precipitation. Soil Sci. Soc. Am. J. 54:198-204.

\title{
Mechanisms and Control of Percolation Losses in Irrigated Puddled Rice Fields
}

\author{
T. P. Tuong,* M. C. S. Wopereis, J. A. Marquez, and M. J. Kropff
}

\section{ABSTRACT}

The low water use efficiency of irrigated lowland rice is partly due to water loss by percolation. Mechanisms of percolation losses were studied in a puddled rice field with a permeable subsoil using simulation models and field experiments. Inclusion of small nonpuddled areas $\left(1.5 \mathrm{~m}^{2}\right.$ per $100 \mathrm{~m}^{2}$ of puddled soil) within the field with $5-\mathrm{cm}$ ponding water depth (PWD) increased field water loss from $2.7 \mathrm{~mm} \mathrm{~d}^{-1}$ to 15 $\mathrm{mm} \mathrm{d}^{-1}$. Under-bund percolation rate (lateral movement of ponded water into the bunds, then vertically down to the water table) was about $10 \mathrm{~mm} \mathrm{~d}^{-1}$ in a 25 by $100 \mathrm{~m}$ field. A one-dimensional mechanistic soil-water balance model, SAWAH, accurately simulated the measured water losses in a homogeneously puddled rice field only when lateral flow toward nonpuddled spots and bunds was prevented. Maintaining shallow PWD did not significantly affect percolation loss through uniformly puddled soil but greatly reduced losses in nonpuddled spots and under-bund percolation. Sealing the bund walls with puddled soil material will decrease the horizontal conductivity of the bunds and may further reduce under-bund percolation.

$\mathrm{R}$ CE PRODUCTION is known to be less water-efficient than that of other crops. The amount of water consumed in the field to produce $1 \mathrm{~kg}$ of rice or each calorie equivalent of rice is significantly greater than for some other important grain crops (Bhuiyan, 1992). Some $5000 \mathrm{~L}$ of water are used to produce $1 \mathrm{~kg}$ of irrigated rice (IRRI, 1993). Because of the increasing urban and industrial demand for water and the increasing costs of development of irrigation schemes, improving WUE is of paramount importance in lowland rice cultivation.

Water use efficiency can be defined agronomically as kilograms of dry matter produced per kilogram of water transpired by the plant (de Wit, 1958) or as the amount of water used (transpired) by the plant relative to total water input in the system. The latter definition is used here because it is also a measure of water losses within

International Rice Research Institute, P.O. Box 933, 1099 Manila, Philippines; M.C.S. Wopereis is also associated with the Dep. of Theoretical Production Ecology, Wageningen Agric. Univ., P.O. Box 430, 6700 AK Wageningen, the Netherlands. Received 30 Nov. 1993. *Corresponding author (t.tuong@cgnet.com).

Published in Soil Sci. Soc. Am. J. 58:1794-1803 (1994) the rice field (field losses) and in the distribution network of irrigation canals (conveyance losses).

This paper deals with field losses that can be analyzed using a field water balance equation:

$$
I+R=E+T+S+P+D+\mathrm{dW}
$$

where $I=$ irrigation supply, $R=$ rainfall, $E=$ evaporation, $T=$ transpiration, $S=$ lateral seepage, $P=$ percolation, $D=$ surface drainage or runoff, and $\mathrm{dW}=$ change in PWD or water storage in the soil profile; all in mm $\mathrm{d}^{-1}$.

Farmers will manipulate water supply $(I)$ depending on water losses $(E+T+S+P+D)$ and as guided by $\mathrm{dW}$. Only $T$ is directly related to biomass accumulation and yield. In practice, it is difficult to separate $T$ and $E$; their sum, evapotranspiration ET $\left(\mathrm{mm} \mathrm{d}^{-1}\right)$, is usually measured or estimated. In a rice-growing area, $D$ from one field is often input for a neighboring field. Similarly, $S$, defined as lateral movement of subsurface water from one field to the other (IRRI, 1965), is mostly offset by incoming seepage from some other fields. It is, therefore, generally assumed that runoff and seepage losses are small, except in peripheral fields adjacent to drainage systems or in terraced rice fields with considerable difference in elevation between fields. From Eq. [1], percolation, defined as the vertical movement of water beyond the root zone to the water table (IRRI, 1965), is the main determinant of the WUE of a paddy field as often recognized by previous investigators (Watanabe, 1992). Percolation has been reported to vary from 0.1 to several hundred $\mathrm{mm} \mathrm{d}^{-1}$ (Greenland, 1985; Hardjoamidjojo, 1992; Sharma and De Datta, 1992; Humphreys et al., 1992b) and is influenced by a variety of environmental and soil-related factors (Wickham and Singh, 1978).

Puddling of rice fields before transplanting or direct seeding reduces percolation losses (Sharma and De Datta, 1985; Humphreys et al., 1992a). Puddling usually com-

Abbreviations: WUE, water use efficiency; PWD, ponding water depth; IRRI, International Rice Research Institute; BLAR, ratio of bund length to field surface area. 
prises one or two passes of plowing about $0.15 \mathrm{~m}$ deep, two or more harrowings, and a final leveling under water-saturated field conditions. Puddling eliminates large soil pores and therefore decreases the hydraulic conductivity of soil (Sharma and De Datta, 1985). Compaction and shearing by farm implements may create a compact zone, often called plow pan, hard pan, plow sole, or traffic pan (Moormann and van Breemen, 1978). In addition, settling and consolidation of dispersed clay particles may occur (Sharma and De Datta, 1985; Adachi and Inoue, 1988; Adachi, 1992). Both compaction and clay translocation reduce the percolation rate.

The reduction of percolation rate through puddling has been studied intensively. Differences in the effectiveness of puddling may arise from the soil types, the technology used, and the conditions under which puddling was conducted. Although authors working with well-controlled microplots (Wopereis et al., 1992b) and in laboratories (Sanchez, 1973; Adachi, 1992; Osari, 1988; Adachi and Inoue, 1988) showed that puddling could reduce infiltration rate in the order of 500 to 1000 times, most field studies report a reduction of less than five times (De Datta and Kerim, 1974; Humphreys et al., 1992b).

Different quantitative relationships between field percolation loss and PWD have been reported. Singh and Wickham (1977) concluded that flooding increased percolation of somewhat porous nonswelling soils but reduced the permeability of low-percolating soils. Tabbal et al. (1992) reported a decrease in percolation rate from $20 \mathrm{~mm} \mathrm{~d}^{-1}$ under 2 to $5 \mathrm{~cm}$ PWD to $9 \mathrm{~mm} \mathrm{~d}^{-1}$ in the continuously saturated regime $(P W D=0 \mathrm{~cm}$ ). Hardjoamidjojo (1992) reported percolation rates of 2.8, 2.8, and $3.8 \mathrm{~mm} \mathrm{~d}^{-1}$ under PWD of $2.5,5.0$, and $7.5 \mathrm{~cm}$, respectively. Ferguson (1970) reported only a slight increase in percolation loss with increasing water depth.

The diversity in research results is due to differences in experimental conditions and the empirical nature of the studies. Interpretations of the results and extrapolation of findings are difficult because the spatial variability of percolation rate is usually not quantified, although it can be an important factor in puddled fields (Wopereis et al., 1992a). Process-oriented research is needed to explain the differences in a mechanistic way.

Most studies considered the loss through the puddled soil in the field within the surrounding bunds (walls of soil, usually about $0.2 \mathrm{~m}$ high and $0.3 \mathrm{~m}$ wide surrounding a rice field) as the only source of percolation loss. However, Walker and Rushton (1984) cited a large number of field results where water balance could not be achieved if it was assumed that only evapotranspiration and vertical percolation through the puddled layer were contributing to water loss. If runoff and seepage losses from one field are a gain to the adjacent field, the only other possible water loss is leakage through the bunds: water moving into and down through the bund to the water table. This under-bund percolation was also reported by IRRI (1987) and Painuli et al. (1988) and can be a very important factor that determines percolation loss in puddled rice fields (T. Woodhead, 1993, personal communication) but is often left out from $P$ in Eq. [1]. In most field studies, rice fields were considered homogeneous and the overall vertical percolation rates of each field were derived from sloping gauge readings. As such, the effects of nonhomogeneity, such as the presence of poorly puddled (or nonpuddled) areas within the rice field and the under-bund water loss, could not be identified and separated.

This study was conducted to develop a quantitative understanding of the effect of soil spatial variability, under-bund percolation, and differences in PWD on field percolation loss in rice fields with a permeable subsoil. These processes were studied using specially designed field experiments in combination with simulation modelling. Guidelines to control such losses are presented.

\section{MATERIALS AND METHODS}

\section{Experimental Site}

The experiments were conducted at the research farm of the IRRI, Los Baños, Philippines $\left(14^{\circ} 30^{\prime} \mathrm{N}, 121^{\circ} 1^{\prime} \mathrm{E}\right)$. The climate has two distinct seasons, wet from July to November and dry from December to June. The soil was classified according to Soil Survey Staff (1992) as an Aquandic Epiaqualf. The $20-\mathrm{cm}$ topsoil contained $42 \%$ clay, $44 \%$ silt, and $14 \%$ sand, whereas the soil horizon just below the topsoil contained $49 \%$ clay, $37 \%$ silt, and $14 \%$ sand. Water balance components were measured in five 11.5 by $6.2 \mathrm{~m}$ plots. A class-A evaporation pan and a rain gauge were installed in a sixth identical plot. The block of six experimental plots was surrounded by a row of 14 buffer plots. All plots were separated by bunds and hydraulically isolated by plastic sheets installed to $0.6-\mathrm{m}$ depth along the center of the bunds. They received the same water treatment to minimize water losses caused by lateral seepage. Plastic installation and bund construction were completed $1 \mathrm{yr}$ before the start of the experiments reported here.

The experimental site had been used during four consecutive seasons for transplanted puddled rice cultivation and was left fallow during the 1992 wet season and the first part of the 1993 dry season. During the first week of February 1993, all experimental and buffer plots were rototilled $10 \mathrm{~cm}$ deep under dry-soil conditions, resulting in soil aggregates of about 3 to $7 \mathrm{~cm}$ diameter. In each of the experimental plots, four rings (55 cm diam. and $55 \mathrm{~cm}$ height) were driven down to a depth of $25 \mathrm{~cm}$. Soil within the rings remained unpuddled (Fig. 1). All plots were submerged for $10 \mathrm{~d}$ and plowed and harrowed twice to a depth of $14 \mathrm{~cm}$ using an IRRI-manufactured microrototiller. In addition to mechanized puddling, the area near the bunds and surrounding the rings were puddled manually to ensure completely puddled conditions within each plot. The plots were further submerged for $10 \mathrm{~d}$ to assure settlement of puddled soil particles (Adachi, 1992). On 24 to 27 February, a plastic barrier supported by a wooden plank was installed at $20 \mathrm{~cm}$ from the bunds, reaching down to the bottom of the puddled zone and preventing water from moving toward the bunds of the experimental fields (Fig. 1). The plastic sheets installed to $0.6 \mathrm{~m}$ depth along the center of the bunds mentioned earlier were not part of this flow barrier. A final puddling was done to all fields on 1 to 5 March. Installation of sloping gauges (Wickham and Singh, 1978), piezometers, walkboards, and trial runs was carried out in March. Collection of experimental data started on 2 Apr. 1993.

\section{Water Management Scenarios}

Three scenarios were applied successively to all experimental plots to quantify losses in the well-puddled field (Scenario 


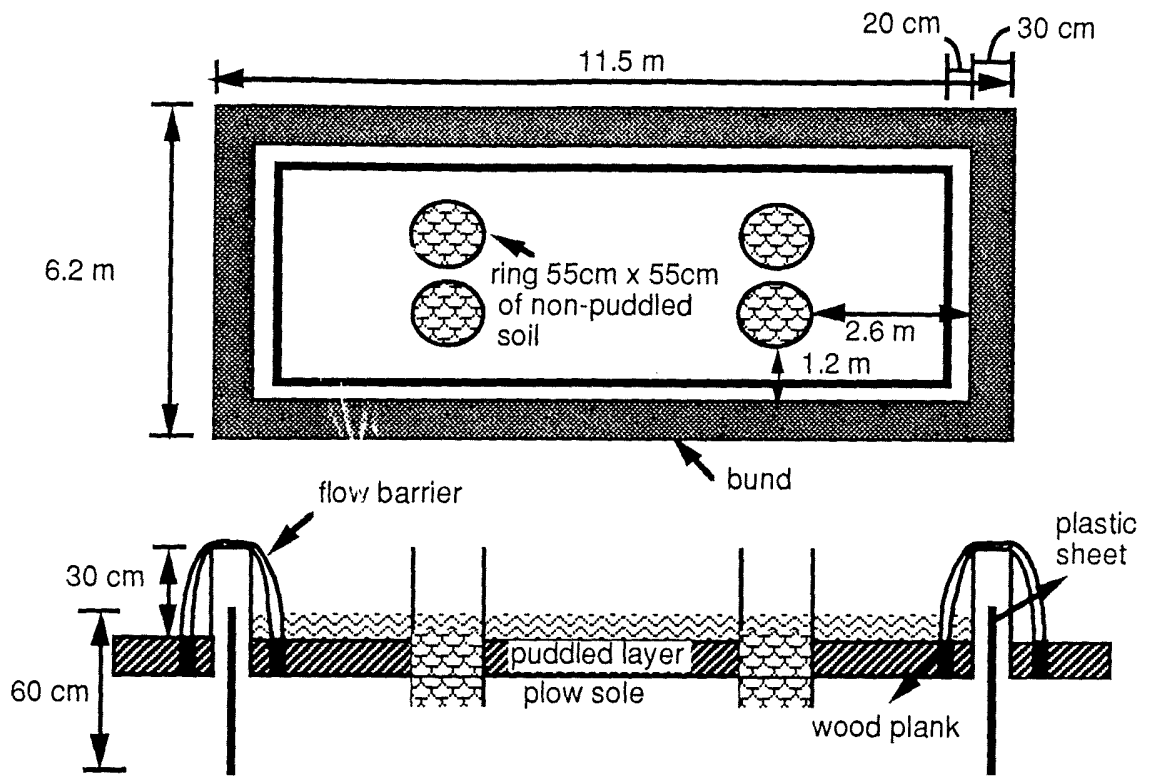

Fig. 1. Schematic layout of an experiment plot (not to scale; piezometers and walkboards are not shown).

1), through the nonpuddled areas within the rings (Scenario 2 ), and by under-bund percolation (Scenario 3). In each scenario, the PWD was $20 \mathrm{~cm}$. Irrigation was applied if PWD dropped below $1 \mathrm{~cm}$.

Scenario 1 (2-28 April). Water level in the well-puddled area within the flow barrier was monitored. Water loss, therefore, consisted of evaporation and vertical percolation through well-puddled soil, excluding the area between the flow barrier and the bund. Water height in the rings was kept at the same level as in the experimental plots to minimize lateral water movement. The volume of water added to the rings was measured independently.

Scenario 2 (29 April-25 May). The rings were removed, thus adding $1 \mathrm{~m}^{2}$ of nonpuddled soil area per $63 \mathrm{~m}^{2}$ of puddled soil area in each plot (excluding the area between bund and flow barrier). Water in the field, therefore, percolated through both puddled and nonpuddled areas. The rings were removed manually by two persons using a cross bar and hook standing on the bunds and walk boards installed in the field.

The (nonpuddled) soil aggregates within the rings had disintegrated by the end of Scenario 1 . To restore the percolation rate within the rings to that of the original nonpuddled condition, soils in the rings were allowed to dry out by evaporation for $1 \mathrm{wk}$ and their surface crusts were broken to a depth of 0 to $10 \mathrm{~cm}$ before the removal of the rings and the start of the water balance monitoring in Scenario 2 .

Scenario 3 (26 May-9 June). After Scenario 2, the flow barrier was removed. Manual puddling was carried out to assure well-puddled condition near the bunds. These activities were conducted without entering the field. Additional water losses could occur due to percolation in the well-puddled area between the flow barrier and the bund and due to the flow toward and into the bund. With the inclusion of the well-puddled area between the flow barrier and the bund, the nonpuddled/ puddled area was reduced to 1:70.

\section{Measurements}

During each scenario, water balance components were measured independently in each of the experimental plots.

Ponding water depth was measured using sloping gauges
(Wickham and Singh, 1978), one for each plot, from 0800 to $1000 \mathrm{~h}$, and before and after irrigation.

Daily water table depth was monitored using five piezometers (one inside each ring and one in the middle of the puddled area) in each experimental plot. During Scenarios 2 and 3, additional piezometers were installed at $1.75-\mathrm{m}$ intervals in between adjacent rings and were read daily to monitor the shape of the water table in between the rings. Similarly, to study the effects of under-bund percolation on the water table near the bund in Scenario 3, an additional five piezometers were installed in a transect perpendicular to a representative bund, one at the center, one at the side of the bund, and others at $0.5-\mathrm{m}$ intervals from the bund. They were monitored daily from 31 May to 4 June. Installation of piezometers was done while standing on the walk boards, without walking in the field.

Saturated hydraulic conductivities of the well-puddled soil, the nonpuddled areas, and the soil underneath the bund were determined at the end of the experiment (June 1993) using equipment and methodology described by Wopereis et al. (1992b). In this method, hydraulic conductivities are derived from in situ infiltration rates and pressure head distributions along a soil column inside a steel cylinder $20 \mathrm{~cm}$ in diameter and $25 \mathrm{~cm}$ in height. An acrylic plastic cover with a water inlet and air outlet is screwed on top of the cylinder and connected to a mariotte buret. Ten small pressure-transducer tensiometers (5 cm long, $6 \mathrm{~mm}$ o.d.) are used to monitor the pressure head distribution in the soil column at $2-\mathrm{cm}$ intervals from 2 - to $20-\mathrm{cm}$ depth from the soil surface

Infiltration rates were determined from mariotte buret readings at 1600 and $1000 \mathrm{~h}$ the following day. M/dday infiltration rates were not used because high temperatures led to erroneous measurements because water was heated up and gas bubbles formed under the plastic cover of the soil column, which hampered water flow from the Mariotte burctte to the soil core.

For each soil condition (well-puddled, nonpuddled, and under-bund), two sets of infiltration rate and pressure head profile measurements were determined at four different positions in the experimental site, which resulted in eight data sets for hydraulic conductivity computation for each soil layer of each soil condition. 
Graphs were prepared of pressure head vs. depth. Best-fitted curves through the data points divided each soil column into sections with clearly different pressure head gradients. With Darcy's Law, the hydraulic conductivity of each of these layers was calculated. Average values and associated standard deviations were also computed.

In situ percolation rate of the nonpuddled spots in Scenario 1 was determined from the amount of water needed to keep water inside the ring at the same level as in their respective plots.

The equipment for measurement of hydraulic conductivity described above was used for in situ measurement of percolation rate in well-puddled soil for three PWDs $(1,10,20 \mathrm{~cm}$ ) by positioning the up of the inner tubing in the mariotte buret at the corresponding heights above the soil surface. For calculation of hydraulıc conductivity, only the percolation rates and pressure head distributions corresponding to $1 \mathrm{~cm}$ PWD were used. Those corresponding to PWDs of 10 and $20 \mathrm{~cm}$ were used for model validation purposes. Thus, data needed for the derivation of the input (i.e., hydraulic conductivity) for the model and for validation were obtained independently.

\section{Simulation Modeling}

The SAWAH model, the one-dimensional mechanistic soilwater balance model (ten Berge et al., 1992) used in this study, solves the general flow equation numerically under given boundary conditions. The model simulates saturated and unsaturated flow occurring simultaneously in different soil profile sections. It uses explicit and implicit schemes for unsaturated and saturated sections of the soil profiles, respectively. The pressure head is defined zero at all saturated-unsaturated interfaces. This condition is used as an internal boundary condition to calculate flow through the distinguished profile sections. The position of these interfaces are determined after each time-step. SAWAH operates with a variable time-step that ranges from 0.0001 to $0.1 \mathrm{~d}$. The hydraulic functions of the soil (i.e., the water retention and hydraulic conductivity characteristics relating volumetric water content and hydraulic conductivity $[k]$ to soil pressure head $[h]$, respectively) need to be specified for each soil layer. Boundary conditions consist of irrigation, rainfall, evaporation, transpiration, and water table depth. Runoff occurs if the computed PWD exceeds a specified bund height. Wopereis et al. (1993b) showed that SAWAH accurately simulated the soil-water balance of rainfed, nonpuddled rice fields.

Simulation runs were conducted for homogeneously wellpuddled soil conditions of the soil columns inside the steel cylinder of the saturated hydraulic conductivity measurement equipment and of Scenario 1. The liquid muddy suspension on the top of the puddled layer was not included in the model because it posed no resistance to vertical water movement (see section below). In SAWAH, the more compacted layer at the lower part of the puddled soil was considered as the top soil layer. The pressure head at the top of this layer was the summation of the PWD and the thickness of the muddy suspension multiplied by its mass density.

The impact of the saturated hydraulic conductivity $\left(k_{s}\right)$ of the least permeable layer of the soil profile on soil pressure head distribution and on in situ percolation rate was investigated. The change in PWD for the field condition under Scenario 1 was simulated. Three values for $k_{\mathrm{s}}$ were used: the average value $\left(k_{\mathrm{s}, \mathrm{m}}\right)$, the average value minus its standard deviation $\left(k_{\mathrm{s}, \mathrm{m}-}\right)$, and the average value plus its standard deviation $\left(k_{\mathrm{s}, \mathrm{m}+}\right)$. For depths $>20 \mathrm{~cm}$, the simulation used the hydraulic parameters $\left(k_{\mathrm{s}}=500 \mathrm{~mm} \mathrm{~d}^{-1}\right)$ of the highly permeable subsoil determined by Wopereis et al. (1993a).

\section{RESULTS AND DISCUSSION \\ In Situ Percolation Rate}

In situ percolation rate of well-puddled and nonpuddled soils are presented in Table 1 . The mean values for well-puddled soil ranged from 2.6 to $3.6 \mathrm{~mm} \mathrm{~d}^{-1}$. These in situ percolation rates agree with values reported for the same area by Wopereis et al. (1992a,b) and Painuli et al. (1988) and are within the range often reported for puddled silty clay rice soils (Hardjoamidjojo, 1992; Sharma and De Datta, 1985).

The mean percolation rates of nonpuddled soil varied greatly, as reflected by their high standard deviations and wide range of observed values (Table 1). There was also a decrease in percolation rate with time (from a mean value of $\approx 600 \mathrm{~mm} \mathrm{~d}^{-1}$ in March to $\approx 300 \mathrm{~mm} \mathrm{~d}^{-1}$ in April) due to disintegration of plowed-soil aggregates under the impact of the water that was added to the rings. The resulting fine particles sealed off the macropores of nonpuddled spots and gradually reduced its percolation rate.

Percolation rate of nonpuddled soil was thus about 100 to 200 times greater than that of puddled soil. This is in agreement with previous findings. Wopereis et al. (1992b) reported a reduction of infiltration rate through puddling by a factor of 500 in a silty clay loam soil. Osari (1988) also found a reduction factor of around 500 to 700 times in a volcanic ash paddy soil. Adachi and Inoue (1988) showed that puddling could reduce hydraulic conductivities of heavy clay soil, clay soil, and loamy sand by factors of 10000,1000 , and 50 times, respectively.

\section{Saturated Hydraulic Conductivity}

Pressure head distributions recorded by tensiometers (Fig. 2), bulk density, and particle-size analyses (Table 2) indicated that the top $20 \mathrm{~cm}$ of well-puddled soil was composed of three distinct layers: an $\approx 10$-cm layer with virtually no resistance to water flow, an $\approx 4-\mathrm{cm}$ transition layer, and an $\approx 6$-cm layer with very low hydraulic conductivity (Table 3). For particle-size distribution and bulk density analyses (Table 2), soils were taken by standard soil samplers of 5-cm height. Depths indicated in Table 2 thus represent approximately the midrange of the three layers described in Table 3.

Table 1. In situ percolation rate of well-puddled (P) and nonpuddled (NP) soil under various ponding water depths (PWD). Standard deviation (SD) and range of observed values (min-max) are indicated.

\begin{tabular}{lccc}
\hline Soil & PWD & Observations & Percolation rate $\dagger$ \\
\hline \multirow{4}{*}{ P } & $\mathrm{cm}$ & no. & $\mathrm{mm} \mathrm{d}^{-1}$ \\
& 1 & 7 & $2.6 \pm 0.2(2.3-3.1)$ \\
NP & 10 & 23 & $2.7 \pm 0.5(2.1-3.9)$ \\
& 20 & 26 & $3.6 \pm 0.7(2.4-5.2)$ \\
NP\$ & $1-5$ & 25 & $565 \pm 233(185-1226)$ \\
& $5-10$ & 20 & $686 \pm 505(183-1730)$ \\
& $1-5$ & 15 & $296 \pm 60(119-365)$ \\
\hline
\end{tabular}

+ Mean \pm SD (min-max).

$\ddagger$ Measured during March 1993.

\& Measured during April 1993. 


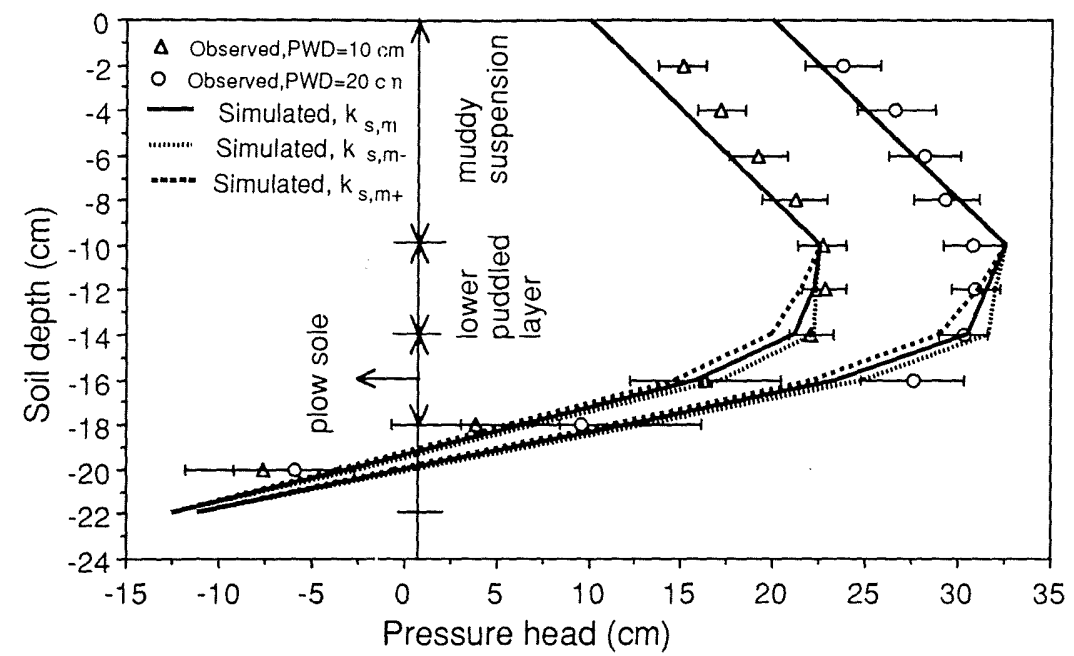

Fig. 2. Measured and simulated pressure head distribution in puddled soil under ponding water depths (PWD) of 10 and 20 cm. Simulations were conducted for three values of saturated conductivity of the least permeable layer: mean $\left(k_{s, m}\right)$, mean plus standard deviation $\left(k_{s, m}+\right)$, mean minus standard deviation $\left(k_{\mathrm{s}, \mathrm{m}-}\right)$. Bars indicate standard deviations of the mean of the values measured at four sites, two sets of readings per site.

The top 10 to $12 \mathrm{~cm}$ consisted of a liquid muddy suspension with 20 to 30 volume percentage of solid particles, and a wet density of 1.3 to $1.4 \mathrm{~g} \mathrm{~cm}^{-3}$. This top layer contained a higher percentage of sand than the lower layers (Table 2). The soil-water pressure head increased linearly with depth (Fig. 2), with a slope of $\approx 1.3$, which is consistent with the specific weight of the layer. This relationship indicates that the top layer did not impose any substantial resistance to water flow.

Deeper down in the puddled soil, the muddy suspension gradually changed into a more compacted and more dense layer of 4 to $6 \mathrm{~cm}$ thickness with more fine particles than the top layer (Table 2). The hydraulic resistance increased accordingly, which resulted in a rather constant pressure head with depth (Fig. 2). Computed hydraulic conductivities ranged from 1.2 to $3.3 \mathrm{~mm} \mathrm{~d}^{-1}$, with an average value of $2.3 \mathrm{~mm} \mathrm{~d}^{-1}$ (Table 3).

Pressure heads decreased rapidly below 15 to $16 \mathrm{~cm}$ depth (Fig. 2). Detailed soil profile observations and penetrometer readings (full data not shown; zero for shallower depths, then $\approx 200 \mathrm{kPa}$ at depth $16.5 \mathrm{~cm}$ ) indicated that this turning point was at the interface of the easily removable puddled layer and the nonpuddled subsoil. The depth with greatest pressure head gradient and, therefore, lowest hydraulic conductivity was found 6 to $8 \mathrm{~cm}$ beneath this interface (i.e., in the plow sole),

Table 2. Particle-size distribution and bulk density of puddled (P) . and nonpuddled (NP) soil material.

\begin{tabular}{|c|c|c|c|c|c|}
\hline Soil & Depth & Clay & Silt & Sand & $\underset{\text { density† }}{\text { Bulk }}$ \\
\hline & $\mathrm{cm}$ & - & $-\%$ & - & $\mathrm{g} \mathrm{cm}^{-3}$ \\
\hline \multirow[t]{3}{*}{$\mathbf{P}$} & $2-7$ & 40.7 & 43.1 & 16.2 & $0.78 \mathrm{a}$ \\
\hline & $10-15$ & 44.5 & 44.1 & 11.4 & $0.89 b$ \\
\hline & $15-20$ & 44.0 & 44.0 & 12.0 & $1.19 \mathrm{~d}$ \\
\hline \multirow[t]{3}{*}{ NP } & $2-7$ & 43.1 & 45.8 & 11.1 & $0.96 \mathrm{bc}$ \\
\hline & $10-15$ & 40.9 & 44.8 & 14.3 & $1.03 c$ \\
\hline & $15-20$ & 43.5 & 43.0 & 13.5 & $1.19 \mathrm{~d}$ \\
\hline
\end{tabular}

$\uparrow$ In a column, means followed by the same letter are not significantly different at the 0.05 level by Duncan's multiple range test. with computed $k_{\mathrm{s}}$ values ranging from 0.34 to $0.76 \mathrm{~mm}$ $\mathrm{d}^{-1}$ (Table 3).

The stratified nature of the puddled layer, the variation of pressure head and the decrease of hydraulic conductivity with increasing depth in the topsoil, is consistent with laboratory and field measurements of Adachi (1990), Adachi (1992), Adachi and Inoue (1988), and Wopereis et al. (1992b).

The similarity between bulk density at $15-$ to $20-\mathrm{cm}$ depth in the well-puddled and the nonpuddled spots (Table 2) suggests that no substantial compaction took place at that depth during puddling. The higher percentage of sand and lower percentage of fine particles in the top layer of the puddled soil suggest a migration of clay and silt from the upper to the lower part of the puddled soil and to the plow sole. This migration was also observed by Adachi and Inoue (1988) who concluded that the low soil permeability just below the puddled layer was mainly caused by blocking of macropores with fine particles translocated through puddling.

Reduction of hydraulic conductivity at greater depth was not observed below the bunds and in the nonpuddled areas. Under the bunds, $k_{s}$ remained as high as $527 \mathrm{~mm}$

Table 3. Saturated hydraulic conductivities of puddled $(\mathrm{P})$ and nonpuddled (NP) soil material within the experimental plots and of soil material under the bund $(B)$ surrounding the experimental plots. The hydraulic conductivity of the top $10 \mathrm{~cm}$ of the puddled soil material was not calculated because of virtually no resistance to water flow. Standard deviation (SD) and range of observed values (min-max) are indicated.

\begin{tabular}{|c|c|c|c|}
\hline Soil & Depth & Observations & $\begin{array}{c}\text { Saturated hydraulic } \\
\text { conductivity } \dagger\end{array}$ \\
\hline \multirow{4}{*}{$\mathbf{P}$} & $\mathrm{cm}$ & no. & $\longrightarrow \mathrm{mm} \mathrm{d}^{-1} \ldots$ \\
\hline & $0-10$ & n.a. $\neq$ & n.a. \\
\hline & $10-14$ & 8 & $2.35 \pm 0.88(1.2-3.3)$ \\
\hline & $14-20$ & 8 & $0.56 \pm 0.15(0.34-0.76)$ \\
\hline NP & $0-20$ & 8 & $23 \pm 12.2(8.8-40.4)$ \\
\hline B & $0-20$ & 8 & $527 \pm 83(423-603)$ \\
\hline
\end{tabular}




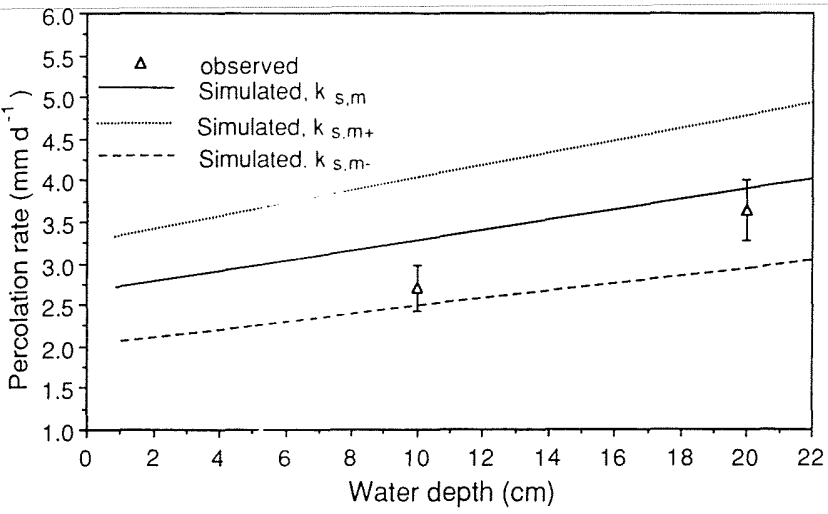

Fig. 3. Measured and simulated in situ percolation rates through puddled soil. Simulations were conducted for three values of saturated conductivity of the least permeable layer: mean $\left(k_{\mathrm{s}, \mathrm{m}}\right)$, mean plus standard deviation $\left(k_{\mathrm{s}, \mathrm{m}+}\right)$, and mean minus standard deviation $\left(k_{\mathrm{s}, \mathrm{m}-}\right)$. Bars indicate standard deviations of the mean of 23 measured values for ponding water depth (PWD) of $10 \mathrm{~cm}$ and 26 values for PWD of $20 \mathrm{~cm}$.

$\mathrm{d}^{-1}$ (Table 3), which is similar to $k_{\mathrm{s}}$ values reported for the subsoil of similar IRRI fields (Wopereis et al., 1993a). High $k_{\mathrm{s}}$ values $\left(200-1200 \mathrm{~mm} \mathrm{~d}^{-1}\right)$ under the bunds were also reported by IRRI (1987). Although particle translocation did not occur during land preparation in the nonpuddled spots, dispersion of plowed soil aggregates under submerged condition resulted in blocking of macropores and caused a reduction in infiltration rate as measured during Scenario 1. The $k_{\mathrm{s}}$ value determined at the end of the experiment (June 1993) was considerably smaller than the average value during the experiment but was still rather high (23 $\mathrm{mm} \mathrm{d}^{-1}$; Table 3$)$.

\section{Simulation Results}

The simulated profile of pressure heads for the wellpuddled soil agreed well with observed values for PWDs of 10 and $20 \mathrm{~cm}$ (Fig. 2). Varying the $k_{\mathrm{s}}$ value of the least permeable layer did not have much effect on the profile (Fig. 2).

The simulated percolation rate using the average $k_{\mathrm{s}, \mathrm{m}}$ of the least permeable layer was slightly larger than the observed in situ measurements (Fig. 3). In absolute terms, however, the difference was very small $(0.4$ and $0.2 \mathrm{~mm} \mathrm{~d}^{-1}$ at PWDs of 10 and $20 \mathrm{~cm}$, respectively). These differences are well within experimental errors and are negligible for all practical purposes.

The simulated percolation rate was very sensitive to a change in $k_{\mathrm{s}}$ of the least permeable layer. A $25 \%$ (standard deviation/mean) variation in $k_{\mathrm{s}}$ resulted in $\approx 20 \%$ variation in simulated percolation rates. As a result, the range of simulated values using $k_{\mathrm{s}, \mathrm{m}}+$ and $k_{\mathrm{s}, \mathrm{m}-}$ encompassed the average measured values and their standard deviations for both 10- and 20-cm PWDs (Fig. 3).

The observed values of field PWD of Scenario 1 were in good agreement with the simulated depths (Fig. 4). Differences between the observed values and the simulated ones with $k_{\mathrm{s}, \mathrm{m}}$ is in the order of $1 \mathrm{~cm}$ after $20 \mathrm{~d}$ of simulation. In other words, the model underestimated the percolation rate by about $0.5 \mathrm{~mm} \mathrm{~d}^{-1}$, which is negligible for most practical purposes. Some differences were exacerbated on days of irrigation (e.g., Day 110, 111, 116) because observed field water levels were taken before and after irrigation at different times of the day whereas SAWAH simulated water depth at the start of the day.

It can be concluded that for all practical purposes and with proper schematization of the puddled layers, SAWAH can accurately simulate pressure head distribution and percolation rate through puddled soil for columnlike one-dimensional flow and for homogeneously puddled field, similar to the conditions of Scenario 1. The low percolation rate of well-puddled soil was mainly determined by the very low conductivity of the least permeable layer beneath the puddled layer, caused by blocking of macropores with fine particles translocated during puddling.

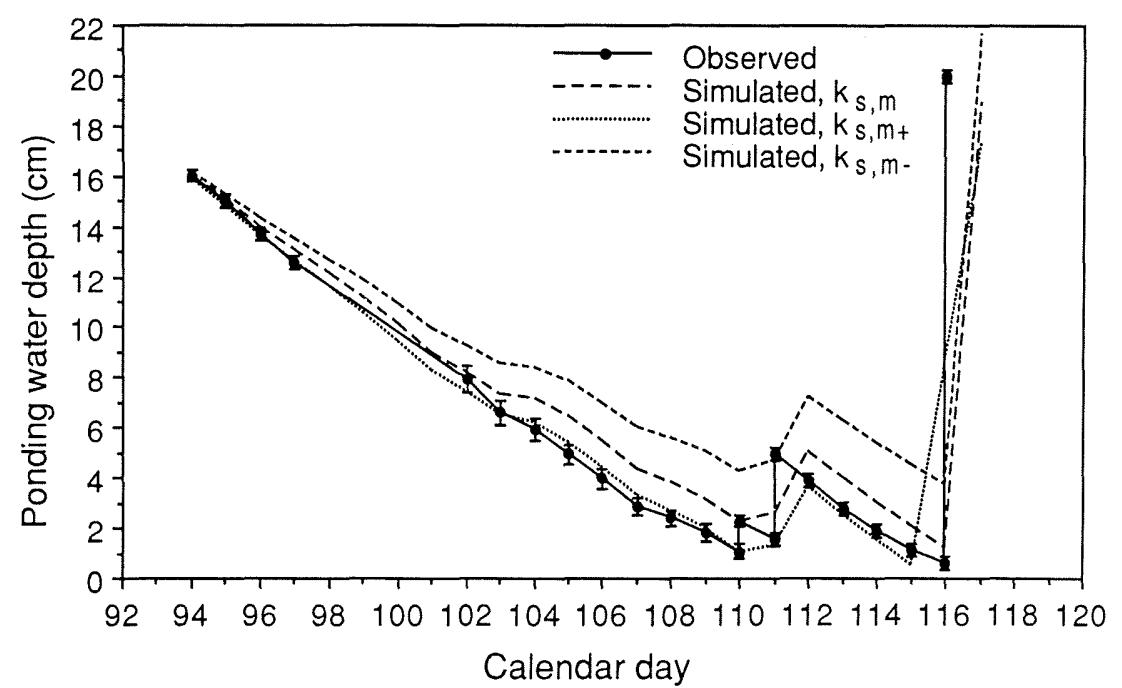

Fig. 4. Measured and simulated ponding water depths in completely puddled field (Scenario 1). Simulations were conducted for three values of saturated conductivity of the least permeable layer: mean $\left(k_{\mathrm{s}, \mathrm{m}}\right)$, mean plus standard deviation $\left(k_{\mathrm{s}, \mathrm{m}+}\right)$, and mean minus standard deviation $\left(k_{\mathrm{s}, \mathrm{m}-}\right)$. Bars indicate standard deviations of the mean of the values measured in five plots. 


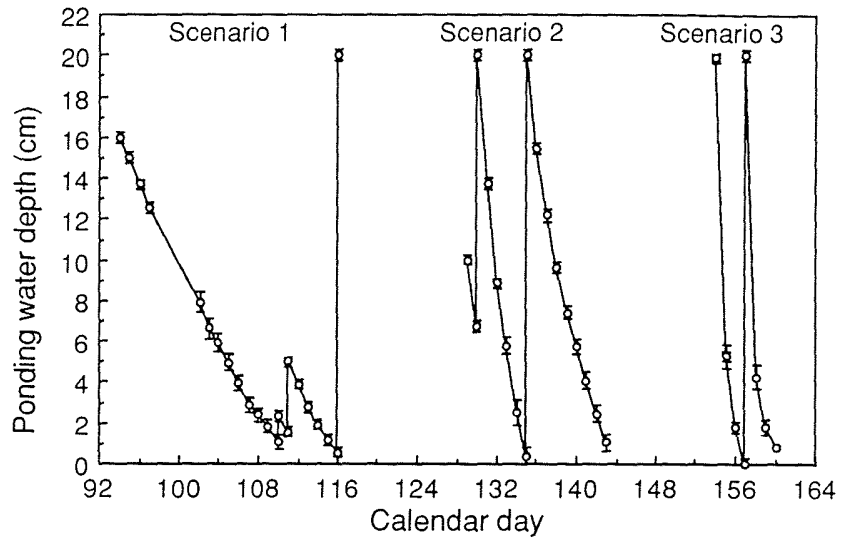

Fig. 5. Measured ponding water depth in three scenarios: Scenario 1, water percolated through well-puddled area only; Scenario 2, percolation loss through $1.5 \%$ nonpuddled area added to Scenario 1; Scenario 3, under-bund percolation added to Scenario 2. Vertical bars indicate standard deviations of the mean values measured in five plots.

\section{Effect of Nonpuddled Spots on Field Percolation Loss}

Figure 5 compares the observed fluctuations of PWD for the three water management scenarios. Differences in evaporation rate and water table depth were small, and virtually no rain was recorded during the PWD monitoring periods (Fig. 6). The differences in the rate of decrease in PWD are, therefore, due to differences in percolation rates that were quantified using Eq. [1] and plotted as a function of PWD (Fig. 7).

For Scenario 2, percolation loss was the sum of percolation in the puddled field within the flow barrier and of percolation through nonpuddled areas. Figure 7 indicates that inclusion of nonpuddled areas increased the field percolation rate drastically. For a PWD of $5 \mathrm{~cm}$, percolation through the puddled soil (Scenario 1) was $\approx 2.7$ $\mathrm{mm} \mathrm{d}^{-1}$, whereas total field percolation (Scenario 2) was $\approx 15 \mathrm{~mm} \mathrm{~d}^{-1}$. Analysis of the components of the water balance showed that water loss through the nonpuddled spots was nearly five times higher than that in the puddled area $\left(0.8\right.$ vs. $\left.0.17 \mathrm{~m}^{3} \mathrm{~d}^{-1}\right)$, although the areal ratio of the former to the latter was only 1:63 (Table 4 ). The

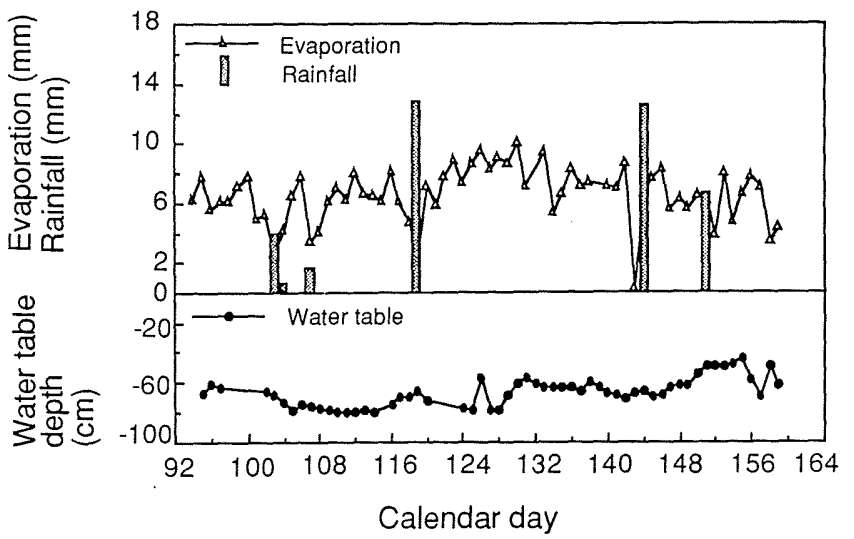

Fig. 6. Evaporation, rainfall, and water table depth (mean of five plots) during the experiment.

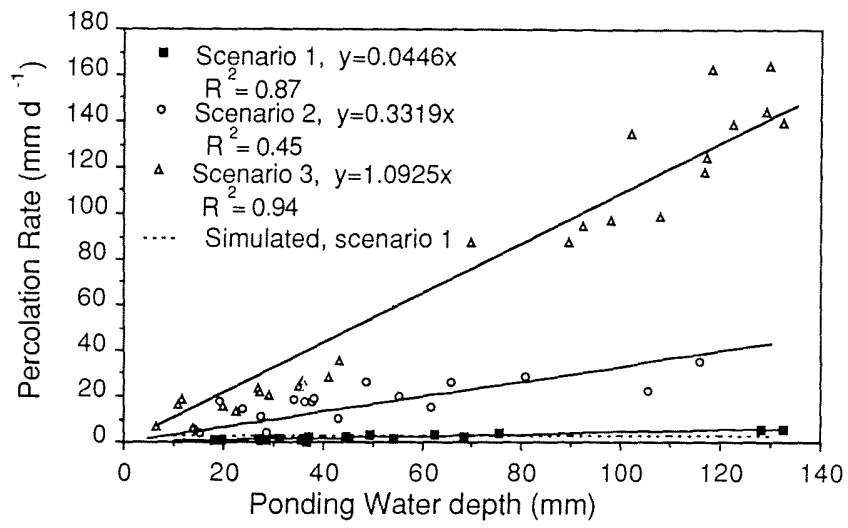

Fig. 7. Percolation rate as a function of ponding water depth for the three scenarios: Scenario 1, water percolated through well-puddled area only; Scenario 2, percolation loss through $1.5 \%$ nonpuddled area added to Scenario 1; Scenario 3, under-bund percolation added to Scenario 2. Linear regressions are forced through zero. All correlations were significant at 0.01 level.

calculated percolation rate in nonpuddled spots amounted to $800 \mathrm{~mm} \mathrm{~d}^{-1}$. This calculated percolation rate is within the range of in situ percolation rate measured for the nonpuddled soil during Scenario 1 (Table 1) and is about 200 to 300 times greater than that of well-puddled soil. The large difference between the two percolation rates illustrates how, in poorly puddled fields, a very small nonpuddled area may largely determine the total loss in the field. Under submergence, the percolation rate of nonpuddled soil may decrease with time (previous section, Table 1). After 2 mo of submergence, however, the percolation rate of nonpuddled soil was still in the order of 100 times greater than the percolation rate of the puddled field (Table 1). Higher values (500-1000) have been reported for the ratio of well-puddled to nonpuddled percolation rates (Wopereis et al., 1992b; Osari, 1988; Adachi and Inoue, 1988). Under these conditions, a ratio of nonpuddled to puddled area of $1: 100$ can easily increase field water loss 4 to 10 times. In practice, such small areas can easily be missed during field tillage opera-

Table 4. Components of percolation loss (with ponding water depth $=5 \mathrm{~cm}$ ) in different scenarios: Scenario 1, water percolated through well-puddled area only; Scenario 2, percolation loss through 1.5\% nonpuddled area added to Scenario 1; Scenario 3 , under-bund percolation added to Scenario 2.

\begin{tabular}{|c|c|c|c|}
\hline & $\begin{array}{c}\text { Scenario } \\
1\end{array}$ & $\begin{array}{c}\text { Scenario } \\
2\end{array}$ & $\begin{array}{c}\text { Scenario } \\
3\end{array}$ \\
\hline Total plot area, $\mathrm{m}^{2}$ & 64.4 & 64.4 & 71.3 \\
\hline Well-puddled area, $\mathrm{m}^{2}$ & 63.4 & 63.4 & 70.3 \\
\hline Nonpuddled area, $\mathrm{m}^{2}$ & n.a. $\dagger$ & 1.0 & 1.0 \\
\hline Bund length, m & n.a. & n.a. & 35.4 \\
\hline Ratio puddled/nonpuddled area & n.a. & 63.4 & 70.3 \\
\hline Field percolation rate, $\mathrm{mm} \mathrm{d}^{-1}$ & 2.7 & 15.0 & 50.0 \\
\hline Total water loss, $\mathrm{m}^{3} \mathrm{~d}^{-1}$ & 0.17 & 0.97 & 3.57 \\
\hline $\begin{array}{l}\text { Water loss through well-puddled } \\
\text { area, } \mathrm{m}^{3} \mathrm{~d}^{-1}\end{array}$ & 0.17 & 0.17 & 0.19 \\
\hline $\begin{array}{l}\text { Water loss through nonpuddled } \\
\text { area, } \mathrm{m}^{3} \mathrm{~d}^{-1} \\
\text { Under-bund water loss, } \mathrm{m}^{3} \mathrm{~d}^{-1}\end{array}$ & $\begin{array}{l}\text { n.a. } \\
\text { n.a. }\end{array}$ & $\begin{array}{l}0.80 \\
\text { n.a. }\end{array}$ & $\begin{array}{l}0.80 \\
2.58\end{array}$ \\
\hline $\begin{array}{l}\text { Percolation rate in nonpuddled } \\
\text { area, mm d } \\
\text { Water loss per meter length of }\end{array}$ & n.a. & 80 & 80 \\
\hline bund, $\mathrm{m}^{3} \mathrm{~d}^{-1}$ & n.a. & n.a. & 0.07 \\
\hline
\end{tabular}

$\dagger$ n.a. $=$ not applicable. 
tions, especially near bunds and corners of rice fields as illustrated by Adachi and Ishiguro (1987).

High percolation raised the water table and recharged the surrounding aquifer, as indicated by the slope of the water table in Fig. 8. Sustained high percolation rate in the nonpuddled spots would depend on the hydraulic conductivity of the subsoil. If vertical and horizontal conductivity were low, the percolation from the nonpuddled areas would be limited and their effect on water loss would not be so predominant.

\section{Under-Bund Percolation Loss}

In Scenario 3, removal of the flow barrier near the bunds allowed water flow into the bunds and greatly increased the field percolation rate (Fig. 5 and 7). At PWD of $5 \mathrm{~cm}$, field percolation rate increased to $50 \mathrm{~mm}$ $\mathrm{d}^{-1}$, more than three times higher than that of Scenario 2 and nearly 20 times higher than that of Scenario 1 (Table 4). Because all experimental plots were surrounded by identical fields and were hydraulically isolated by plastic sheets installed along the center of the bunds, the whole experimental area was surrounded by a buffer zone of similar conditions, no net lateral movement across the bunds could occur. Percolation in the additional puddled area in between flow barrier and bund would account for $<1 \%$ of the additional loss $\left(0.19 \mathrm{~m}^{3} \mathrm{~d}^{-1}\right.$ in $70.3 \mathrm{~m}^{2}$ and $0.17 \mathrm{~m}^{3} \mathrm{~d}^{-1}$ in $63.4 \mathrm{~m}^{2}$ for Scenario 3 and 2 , respectively; Table 4). Most of the extra water loss must, therefore, relate to water flow into the bunds.

The vertical conductivity under the bund was very high (527 $\mathrm{mm} \mathrm{d}^{-1}$; Table 3). Assuming that horizontal hydraulic conductivity of the bund was of the same magnitude, there would be little resistance to water flow into the bunds from fields from both sides and downward to the underlying water table. Evidence of this recharge is provided by the rise in water table under and near the bunds (Fig. 9), similar to what is shown in Fig. 8 for nonpuddled spots. This under-bund percolation loss should be distinguished from lateral seepage ( $S$ in Eq. [1]), which is defined as horizontal flow through the bunds from one field to the other (Wickham and Singh,

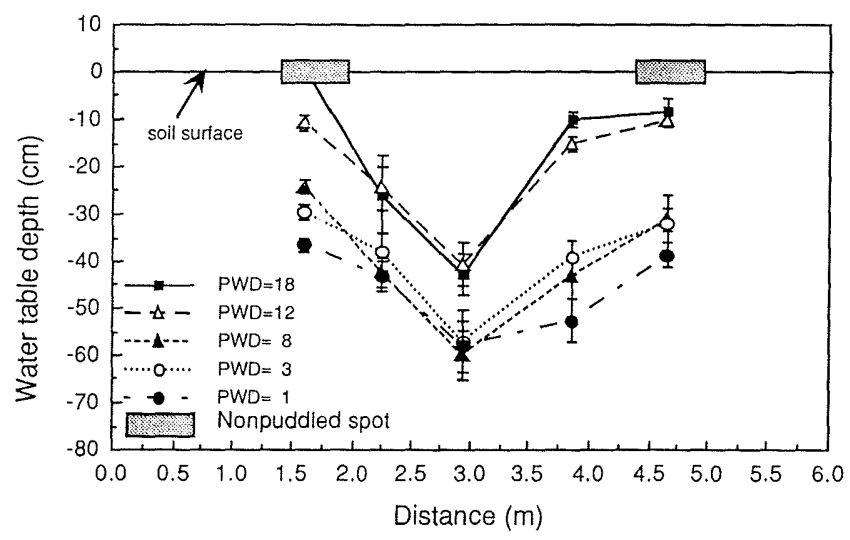

Fig. 8. Water table depth under nonpuddled and puddled areas during Scenario 2 (well-puddled field plus $1.5 \%$ nonpuddled area). Bars indicate standard deviations of the mean values measured in five plots for each ponding water depth (PWD, in centimeters).
1978). Whereas $S$ often results in no net loss to the field, except in peripheral fields, the under-bund percolation occurs in every field even in completely flat areas. Walker and Rushton (1984) identified under-bund percolation, which they called lateral percolation, as the main cause of low WUE in certain irrigated rice fields.

In our experiment, the under-bund percolation loss can be calculated from the difference between Scenarios 2 and 3 (Fig. 7; Table 4). Under PWD of $5 \mathrm{~cm}$, this amounts to $3.57 \mathrm{~m}^{3} \mathrm{~d}^{-1}$ for an 11.5 by $6.2 \mathrm{~m}$ plot, or for each meter of bund around the field, $0.07 \mathrm{~m}^{3}$ of water flows to the underlying aquifer each day. For PWD of $10 \mathrm{~cm}$, this flow to the aquifer increases to $0.16 \mathrm{~m}^{3} \mathrm{~d}^{-1}$. These flows are in good agreement with Walker and Rushton (1984) who gave an estimate of about $0.14 \mathrm{~m}^{3} \mathrm{~d}^{-1}$ per meter of bund. Water loss due to under-bund percolation depends on many factors, including the horizontal conductivity of the subsoil, hydraulic conditions of the surrounding fields, and the ratio BLAR. The greater the latter, the more pronounced the effect of under-bund percolation. In our experiment, the effect of under-bund percolation was particularly high, partly because of the high BLAR $\left(0.5 \mathrm{~m}^{-1}\right)$ of the experimental fields. The contribution of the under-bund percolation to the total water loss might, however, be even higher in normal-sized experiment fields, which range from 25 to $40 \mathrm{~m}^{2}$. For example, Painuli et al. (1988) reported that the ratio of seepage-plus-percolation (as measured by sloping gauges) to percolation (measured by double-ring infiltrometers) ranged from 18 to 80 for $25-\mathrm{m}^{2}$ experimental plots $\left(\mathrm{BLAR}=0.8 \mathrm{~m}^{-1}\right)$. Because in Painuli et al. (1988), individual plots were isolated by polyethylene sheets installed vertically to $0.5-\mathrm{m}$ depth, the increased water loss could be interpreted as due to under-bund percolation rather than to seepage. Similarly, much of the tenfold difference between seepage-pluspercolation and percolation in 30 by $15 \mathrm{~m}$ plots reported by Wopereis et al. (1994) might have been attributed to under-bund percolation.

In a typical farmer's field of 25 by $100 \mathrm{~m}$ (BLAR $=$ $0.1 \mathrm{~m}^{-1}$ ) assuming an average value of $0.1 \mathrm{~m}^{3} \mathrm{~d}^{-1}$ per

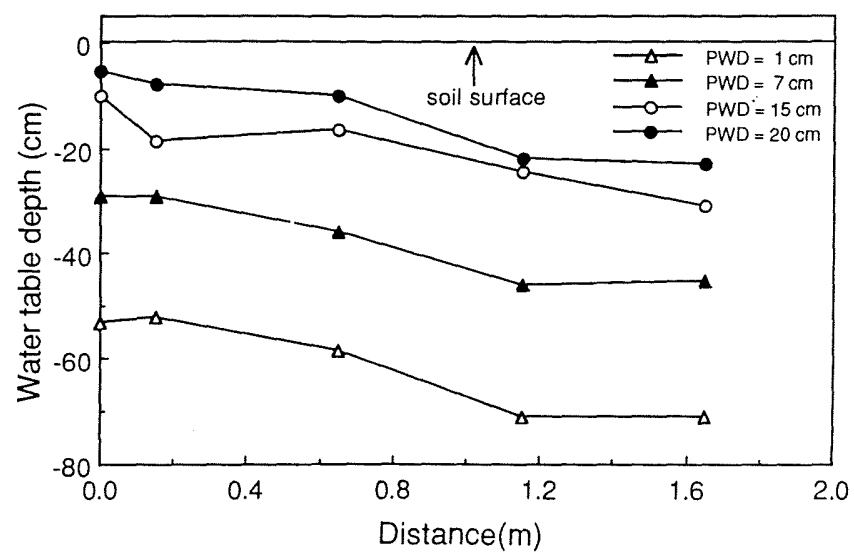

Fig. 9. Water table depth measured in five piezometers installed in a representative plot at various ponding water depths (PWD) during Scenario 3 (well-puddled field plus $1.5 \%$ nonpuddled area and under-bund percolation). Distances were measured from the center of a bund, which was $30 \mathrm{~cm}$ wide. 
meter of bund, under-bund percolation will be in the order of $25.0 \mathrm{~m}^{3} \mathrm{~d}^{-1}$. This is equivalent to a percolation rate of $10 \mathrm{~mm} \mathrm{~d}^{-1}$, three to five times higher than the percolation rate of a well-puddled silty clay loam soil. Neglecting under-bund percolation in water or nutrient balance studies will, therefore, lead to errors in calculation, especially when rice fields are small and when the subsoil is permeable.

\section{Effect of Ponding Water Depth on Percolation Loss}

Table 1 indicates that the change in in situ percolation rate of well-puddled soil was not substantial when PWD was increased from 1 to $20 \mathrm{~cm}$ and was within the measurement errors. Field percolation rate measured in Scenario 1 increased very slightly with PWD (Fig. 7). Similarly, simulation predicted a slow linear increase of percolation rate with respect to PWD (Fig. 3 and 7). A tenfold increase in PWD from 1 to $10 \mathrm{~cm}$ was accompanied by a change from 2.75 to $3.25 \mathrm{~mm} \mathrm{~d}^{-1}$ in simulated percolation rate using $k_{\mathrm{s} \text {, }}$ (Fig. 3). The fact that percolation rate was not sensitive to PWD was due to the very low conductivity, which created a large hydraulic gradient across the semi-impermeable plow sole (Fig. 2). Furthermore, because the pressure head at the top soil layer (i.e., the more compacted layer at the lower part of the puddled soil) was the summation of PWD and the thickness of the muddy suspension multiplied by its mass density, increasing the PWD tenfold did not mean that this pressure and the gradient were increased tenfold. Further simulations with various $k_{\mathrm{s}}$ indicated that a reduction in PWD substantially reduced percolation rate through puddled soil only if $k_{s}$ of the least permeable layer was $>10 \mathrm{~mm} \mathrm{~d}^{-1}$. Percolation rates increased significantly with PWD in Scenarios 2 and 3 (Fig. 7). The increase was thus mainly due to increased water loss through nonpuddled spots and under the bunds where conductivity was very high (Table 3 ). More complex numerical models that allow for lateral flow into the bunds (e.g., Walker and Rushton, 1984) are needed to simulate water flow under these circumstances.

Quantitative relationships between percolation loss and PWD in puddled rice fields thus depend on how the percolation is determined. Percolation rate determined by infiltration rings (e.g., Hardjoamidjojo, 1992) is likely to be less sensitive to changes in PWD than that determined by sloping gauges (e.g., Tabbal et al., 1992) because the former excludes under-bund percolation and loss through nonpuddled or less well-puddled spots outside the rings. Our results confirm previous findings (Tabbal et al., 1992) that substantial water savings can be expected if shallow PWDs are maintained in rice fields with a relatively permeable subsoil. Shallow PWD reduces the wetted area of the bunds and limits the amount of water infiltrating laterally into the bund. Furthermore, if PWD is kept very low or if the field is maintained at saturation point (e.g., Tabbal et al., 1992), water loss is greatly reduced because the unevenness of the soil surface prevents lateral water movement to the bunds and to the nonpuddled areas. Sealing the bund walls with mud from the plow layer also reduces the lateral infiltration into the bunds. Such measures, although practiced by farmers, are not yet well documented. On a regional scale, such measures could have a major impact. Wopereis (1993) determined the soil hydraulic properties of seven major soil types under rice cropping in Tarlac Province in the Philippines. Two of these soils had relatively permeable subsoils (as evidenced by a large hydraulic conductivity near saturation) occupying 50000 ha or $40 \%$ of potentially suitable rice land within the province.

\section{CONCLUSIONS}

The sealing of macropores with fine particles translocated during puddling predominantly caused the formation of a semi-impermeable layer just beneath the puddled topsoil. This semi-impermeable layer was the single most important layer and was responsible for the low percolation rate of well-puddled soil.

Processes of percolation in flooded, puddled rice fields could be studied mechanistically with the one-dimensional simulation model SAWAH. It accurately predicted changes in PWD, infiltration rate, and pressure head gradients with depth under well-puddled soil conditions. The hydraulic conductivity of nonpuddled spots and of soil material under bunds remained large because of the absence of the semi-impermeable layer. A small area of nonpuddled soil (in the order of $1 \%$ of puddled soil) increased field percolation losses by a factor five, and under-bund percolation caused a further two to fivefold increase, depending on the size of the field. For permeable subsoil conditions, the occurrence of these losses in the field imposed limitations to the practical application of SAWAH and similar models that use point-measured soil hydraulic properties as input.

Neglecting these losses in water or nutrient balance studies will lead to erroneous results, especially if rice fields are small. Because experiments are often carried out in relatively small plots, it is important not to generalize experiment results to farmers' fields without taking into account the effect of under-bund percolation losses and preferential flow to nonpuddled or poorly puddled areas.

Maintaining shallow PWD did not significantly affect the percolation rate of well-puddled soil but greatly reduced losses through nonpuddled or poorly puddled spots and under-bund percolation. It is, therefore, an important measure to increase the WUE of rice fields in areas with permeable subsoil.

The importance of the processes under study was illustrated by the large surface area of potentially suitable rice land with relatively permeable subsoil in the Province of Tarlac in the Philippines.

\section{REFERENCES}

Adachi, K. 1990. Effects of rice-soil puddling on water percolation. p. 146-151. In Trans. 14th Int. Cong. Soil Sci. Kyoto, Japan. 1218 Aug. 1990. Vol. 1. ISSS, Wageningen, the Netherlands.

Adachi, K. 1992. Effect of puddling on rice-soil physics: Softness of puddled soil and percolation. p. 220-231. In V.V.N. Murty and K. Koga (ed.) Soil and water engineering for paddy field 
management. Proc. Int. Workshop on Soil and Water Engineering for Paddy Field Management. Bangkok, Thailand. 28-30 Jan. 1992. Asian Inst. Technol., Bangkok.

Adachi, K., and $\mathrm{H}$. Inoue. 1988. Effects of puddling on percolation control of paddy field. p 917-928. In Proc. First Int. Symp. on Paddy Soil Fertility. Chiangmai, Thailand. 6-13 Dec. 1988. Chiang Mai Univ., Chiang Miı. Thailand.

Adachi, K., and M. Ishiguro 1987. Water requirement and percolation. p. 35-48. In Physkal measurements in flooded rice soils. The Japanese methodologic IRRI. Los Baños, Laguna, Philippines.

Bhuiyan, S.I. 1992. Water management in relation to crop production: Case study on rice. Outl(x)h Agric. 21(4):293-299.

De Datta, S.K., and M.S Kerm 1974. Water and nitrogen economy of rainfed rice as affected hy soil puddling. Soil Sci. Soc. Am. Proc. 38:515-518.

de Wit, C.T. 1958. Transpiration and crop yields. Verslag Landbouwkundig Onderzoek, Wagenıngen Agric. Univ., Wageningen, the Netherlands.

Ferguson, J.A. 1970. Eftert of flood depth on rice yield and water balance. Arkansas Farm Res. 19(3):4.

Greenland, D.J. 1985. Ph! skal aspects of soil management for ricebased cropping system - p. 1-16. In Soil physics and rice. IRRI, Los Baños, Philippinc-

Hardjoamidjojo, S. 1992 The effect of flooding and method of water application on water requirements and yield of wetland paddy. $p$. 63-71. In V.V.N. Murt! and K. Koga (ed.) Soil and water engineering for paddy field management. Proc. Int. Workshop on Soil and Water Engineering for Paddy Field Management. Bangkok, Thailand. 28-30 Jan. 1992. Asian Inst. Technol., Bangkok.

Humphreys, E., W.A. Muirhead, and B.J. Fawcett. 1992a. The effect of puddling and compaction on deep percolation and rice yield in temperate Australia. p. 212-219. In V.V.N. Murty and K. Koga (ed.) Soil and water engineering for paddy field management. Proc. Int. Workshop on Soil and Water Engineering for Paddy Field Management. Bangkok, Thailand. 28-30 Jan. 1992. Asian Inst. Technol., Bangkok.

Humphreys, L., W. Muirhead, B.J. Fawcett, and J. Townsend. 1992b. Minimizing deep percolation from rice. Farmers Newsletter (Griffith, NSW, Australia) 172:41-43.

IRRI. 1965. Annual report for 1964. IRRI, Los Baños, Philippines. IRRI. 1987. Annual report for 1986. IRRI, Los Baños, Philippines. IRRI. 1993. Rice research in a time of change. IRRI's medium-term plan for 1994-1998. IRRI, Los Baños, Philippines.

Moormann, F.R., and N. van Breemen. 1978. Rice, soil, water, land. IRRI, Los Baños, Philippines.

Osari, H. 1988. Analysis of stirred and compacted operation on puddling by a tractor. (in Japanese, with English abstract) Trans. Jpn. Soc. Irrig. Drain. Reclam. Eng. 134:1-7.

Painuli, D.K., T. Woodhead, and M. Pagliai. 1988. Effective use of energy and water in rice soil puddling. Soil Tillage Res. 12:149161 .

Sanchez, P.A. 1973. Puddling tropical rice soils: 2. Effects of water loses soil. Soil Sci. 115:303-308.

Sharma, P.K., and S.K. De Datta. 1985. Effects of puddling on soil physical properties and processes. p. 217-234. In Soil physics and rice. IRRI, Los Baños, Philippines.
Sharma, P.K., and S.K. De Datta. 1992. Response of wetland rice to tropical conditions. p. 109-107. In V.V.N. Murty and K. Koga (ed.) Soil and water engineering for paddy field management. Proc. Int. Workshop on Soil and Water Engineering for Paddy Field Management. Bangkok, Thailand. 28-30 Jan. 1992. Asian Inst. Technol., Bangkok.

Singh, V.P., and T.H. Wickham. 1977. Water movement through wet soils. In Symp. on soils and rice. Vol. 2. IRRI, Los Baños, Philippines.

Soil Survey Staff. 1992. Keys to soil taxonomy. Soil Manage. Support Serv. Tech. Monogr. 19. 5th ed. Pocahontas Press, Blacksburg, VA.

Tabbal, D.F., R.M. Lampayan, and S.I. Bhuiyan. 1992. Waterefficient irrigation technique for rice. p. 146-159. In V.V.N. Murty and K. Koga (ed.) Soil and water engineering for paddy field management. Proc. Int. Workshop on Soil and Water Engineering for Paddy Field Management. Bangkok, Thailand. 28-30 Jan. 1992. Asian Inst. Technol., Bangkok.

ten Berge, H.F.M., D.M. Jansen, K. Rappoldt, and W. Stol. 1992. The water balance module SAWAH: User's guide and outline. CABO-TPE Simulation Rep. Ser. 22. CABO, Wageningen, the Netherlands.

Walker, S.H., and K.R. Rushton. 1984. Verification of lateral percolation losses from irrigated rice fields by a numerical model. J. Hydrol. (Amsterdam) 71:335-351.

Watanabe, T. 1992. Water budgets in paddy field lots. p. 1-11. In V.V.N. Murty and K. Koga (ed.) Soil and water engineering for paddy field management. Proc. Int. Workshop on Soil and Water Engineering for Paddy Field Management. Bangkok, Thailand. 28-30 Jan. 1992. Asian Inst. Technol., Bangkok.

Wickham, T.H., and V.P. Singh. 1978. Water movement through wet soils. p. 337-357. In Soils and rice. IRRI, Los Baños, Philippines.

Wopereis, M.C.S. 1993. Quantifying the impact of soil and climate variability on rainfed rice production. Ph.D. diss. Wageningen Agric. Univ., Wageningen, the Netherlands.

Wopereis, M.C.S., B.A.M. Bouman, M.J. Kropff, H.F.M. ten Berge, and A.R. Maligaya. 1994. Understanding the water use efficiency of flooded rice fields. I. Validation of the soil-water model SAWAH. Agric. Water Manage. (Amsterdam) (in press).

Wopereis, M.C.S., M.J. Kropff, J.H.M. Wösten, and J. Bouma. 1993a. Sampling strategies for measurement of soil hydraulic properties to predict rice yield using simulation models. Geoderma 59: $1-20$.

Wopereis, M.C.S., A. Stein, J. Bouma, and T. Woodhead. 1992a. Sampling number and design for measurements of infiltration rates in puddled rice fields. Agric. Water Manage. (Amsterdam) 21: 281-295.

Wopereis, M.C.S., J.H.M. Wösten, J. Bouma, and T. Woodhead. 1992b. Hydraulic resistance in puddled rice soils: Measurement and effects on water movement. Soil Tillage Res. 24:199-209.

Wopereis, M.C.S., J.H.M. Wösten, H.F.M. ten Berge, T. Woodhead, and E.M. de San Agustin. 1993b. Comparing the performance of a soil-water balance model using measured and calibrated hydraulic conductivity data: A case-study for dry land rice. Soil Sci. 156: 133-140. 